\title{
Effects of competition and mowing on growth and reproduction of the invasive plant Erigeron annuus at two contrasting altitudes
}

Journal Article

Author(s):

Trtikova, Miluse

Publication date:

2009

Permanent link:

https://doi.org/10.3929/ethz-b-000019858

Rights / license:

In Copyright - Non-Commercial Use Permitted

Originally published in:

Botanica Helvetica 119(1), https://doi.org/10.1007/s00035-009-0050-8 


\title{
Effects of competition and mowing on growth and reproduction of the invasive plant Erigeron annuus at two contrasting altitudes
}

\author{
Miluse Trtikova
}

Received: 16 February 2009/Accepted: 7 June 2009/Published online: 14 July 2009

(C) Birkhäuser Verlag, Basel/Switzerland 2009

\begin{abstract}
Invasive plants are often abundant at frequently disturbed sites such as roadsides, because they benefit from reduced competition or increased nutrient availability. In Switzerland, roadsides are subjected to regular mowing, and to persist in these sites, plants must be able to compensate for the biomass removal. However, the ability to tolerate competition and mowing might decline under less favourable growth conditions, such as those at higher altitudes. I investigated how competition and mowing affect growth and reproduction of Erigeron annuus (L.) Pers., an invasive plant common on Swiss roadsides, and how these effects change with altitude. The experiment was replicated in common gardens at altitudes of $400 \mathrm{~m}$ and $1,000 \mathrm{~m}$ asl, representing growth conditions in the main distribution area of E. annuus and at its altitudinal limit, respectively. Vegetative growth was negatively affected by competition at both sites, but especially at 1,000 $\mathrm{m}$. The number of capitula was not affected by competition at $400 \mathrm{~m}$, but was reduced at $1,000 \mathrm{~m}$. Plants regrew vigorously after mowing in both gardens. The effects of mowing on reproductive output were positive at $400 \mathrm{~m}$, but negative at $1,000 \mathrm{~m}$. These results imply that E. annuus is able to tolerate competition and mowing at low altitudes, but both of these factors hinder its reproduction at higher altitudes.
\end{abstract}

Zusammenfassung Invasive Neophyten kommen an gestörten Standorten besonders häufig vor, da sie dort weniger Konkurrenz oder eine höhere Nährstoffverfügbarkeit

Responsible Editor: Sonja Wipf.

M. Trtikova $(\bowtie)$

Institute of Integrative Biology, ETH Zurich,

8092 Zurich, Switzerland

e-mail: miluse.trtikova@env.ethz.ch vorfinden. In der Schweiz sind regelmässig gemähte Strassenränder wichtige Lebensräume und Ausbreitungskorridore für invasive Pflanzen. Offenbar gelingt es den Pflanzen, die Mahdverluste zu kompensieren und sich dennoch zu vermehren. Die Fähigkeit von Pflanzen, Konkurrenz oder Störungen zu ertragen, nimmt in der Regel unter ungünstigen Wachstumsbedingungen ab. Deshalb könnte man erwarten, dass invasive Pflanzen mit zunehmender Meereshöhe aufgrund des kälteren Klimas durch Konkurrenz und Mahd stärker betroffen werden. Hier wurde untersucht, ob Konkurrenz und Mahd das Wachstum und die Fortpflanzung des einjährigen Berufkrauts, Erigeron annuus (L.) Pers., je nach Meereshöhe unterschiedlich beeinflussen. Dazu wurde ein Experiment in zwei Gärten auf 400 und 1,000 m ü.M. angelegt, wobei der obere Garten der heutigen Verbreitungsgrenze von E. annuus entspricht. Konkurrenz reduzierte das vegetative Wachstum an beiden Orten, jedoch stärker auf 1,000 m. Die Anzahl Blütenköpfe wurde nur auf 1,000 m durch Konkurrenz reduziert. Nach einer Mahd trieben die Pflanzen in beiden Gärten schnell wieder aus. Die Mahd erhöhte die Anzahl Blütenköpfe auf $400 \mathrm{~m}$ und senkte sie auf 1,000 m. Diese Ergebnisse bedeuten, dass E. annuus in tiefen Lagen Mahd und Konkurrenz ertragen kann, während in höheren Lagen beide Faktoren seiner Ausbreitung entgegenwirken.

Keywords Altitudinal limit - Common garden · Disturbance · Introduced plants · Roadsides · Swiss Alps

\section{Introduction}

Many introduced plant species become successful invaders not because they are more competitive than native species, but because they benefit more from nutrient-rich or disturbed conditions associated with human activities (Daehler 
2003). For example, establishment of Centaurea diffusa, one of the most problematic introduced plant species in western North America, was shown to be enhanced by high resource availability, and both the densities and size of $C$. diffusa increased when competition was also reduced by partially removing resident grass vegetation (Seastedt and Suding 2007). Similarly, Petryna et al. (2002) observed that the establishment and persistence of six plant species, including Cirsium vulgare and Oenothera erythrosepala that were introduced from Europe and have become abundant in the mountain grasslands in central Argentina, strongly depended on soil disturbances and aboveground biomass removal by cutting and burning.

Introduced plants may recover better than native ones from biomass removal (Kimball and Schiffman 2003), and mowing or grazing can therefore increase their canopy cover (Brandon et al. 2004). However, a plant's ability for compensatory regrowth generally declines as competition increases and/or nutrient availability decreases (Maschinski and Whitham 1989). In addition, the degree of compensation is also sensitive to the timing of the biomass removal, as clipped plants postpone flowering, and therefore, require a longer vegetation period to reproduce (Lennartsson et al. 1998). Consequently, plants will compensate for biomass removal less well in regions with short growing seasons such as high altitudes and latitudes (Lennartsson et al. 1998). Thus, mowing might serve as an effective management tool to restrict the growth and spread of invasive plants in mountain regions, although it might be ineffective to suppress the species in the lowland regions.

In this study I investigate how competition and mowing affect the growth and reproductive output of the invasive plant Erigeron annuus (L.) Pers. (Asteraceae), a winter annual native to North America, but introduced and now widespread in Europe. In Switzerland, E. annuиs mostly occurs in the lowlands and is rarely found in the Alps above $1,000 \mathrm{~m}$ (Becker et al. 2005). It is especially abundant along railways and roads, suggesting that frequent disturbances that reduce competition from resident vegetation might be necessary for its successful establishment. Such sites are also subject to regular mowing, and to persist in these environments E. annuиs must be able to compensate well for biomass removal. Frey et al. (2003) reported that $E$. annuus regrew well after mowing. They also observed a strong plastic response in leaf shape to the extent where mown plants may sometimes have been misidentified as belonging to another taxon. This plasticity and tolerance to mowing might also have contributed to the specie's invasiveness, however, it is unknown whether E. annuus is able to maintain its fitness and respond plastically to the mowing under less favourable growth conditions at higher altitudes.
To investigate how E. annuus responds to competition and mowing, and whether these responses change with altitude, I conducted a common garden experiment at $400 \mathrm{~m}$ and at $1,000 \mathrm{~m}$ asl. The lower altitude represented conditions in the main area of E. annuus distribution, whereas the higher altitude was close to the current altitudinal limit in Switzerland. I focused on the following questions: (1) How does E. annuus respond to competition and mowing? (2) Is its fitness less affected at $400 \mathrm{~m}$ than at $1,000 \mathrm{~m}$ ? (3) Does phenotypic plasticity in response to mowing differ between 400 and 1,000 m?

\section{Materials and methods}

\section{Plant material}

Erigeron annuus is a winter annual, i.e. seeds usually germinate in late summer and rosettes are formed in autumn. Overwintering rosettes then bolt and flower the following year. The species is triploid $(2 n=27)$ and predominantly apomictic, producing a large number $(<50,000)$ of tiny $(25 \mu \mathrm{g})$, wind-dispersed seeds (Stratton 1989).

Seeds were collected from 35 E. anпииs plants growing along major roads in the Swiss Alps in August 2004. Plants were at least $2 \mathrm{~m}$ apart and originated from 21 different sites ranging from 325 to $965 \mathrm{~m}$. These sites were at least $2 \mathrm{~km}$ apart. In the following year, seeds were sown in a common garden at $400 \mathrm{~m}$ in order to produce a new generation of seeds free of any maternal effects from their original sites; these seeds were collected in August 2005. Although most populations of $E$. annuиs exhibit a high degree of genetic variation, suggesting that sexual reproduction does occasionally occur (Edwards et al. 2006), the seeds from one mother plant are usually genetically identical; therefore, I refer to them as 'clones' hereafter.

\section{Plant cultivation}

In December 2005 seeds were germinated on wet filter paper in Petri dishes in a climate chamber (day/night temperatures of $25 / 16^{\circ} \mathrm{C}$ ). After 10 days seedlings were transplanted into seedling trays filled with standard potting soil (Universalerde Capito, Landi Schweiz). To simulate winter conditions, seedling trays were kept for the next 13 weeks in growth cabinets where day/night temperatures were progressively reduced from $20 / 12$ to $12 / 4^{\circ} \mathrm{C}$. For the next 5 weeks the seedling trays were moved outdoors to the institute terrace, and they were transported to the common gardens at $400 \mathrm{~m}$ on 3 May 2006 and at 1,000 m on 5 May 2006. During the experiment the monthly mean 
Table 1 Monthly mean temperatures $\left({ }^{\circ} \mathrm{C}\right)$ in the common gardens at $400 \mathrm{~m}$ and at $1,000 \mathrm{~m}$ asl (M. Zeeman unpubl. data)

\begin{tabular}{lllllll}
\hline & May & June & July & August & September & October \\
\hline $400 \mathrm{~m}$ & 13.3 & 17.5 & 21.7 & 15.0 & 16.7 & 12.4 \\
$1,000 \mathrm{~m}$ & 10.4 & 14.9 & 19.4 & 11.8 & 14.9 & 11.1 \\
\hline
\end{tabular}

temperatures were on average $2.4^{\circ} \mathrm{C}$ higher at $400 \mathrm{~m}$ than at $1,000 \mathrm{~m}$ (Table 1).

\section{Treatments}

Common gardens were set up at the ETH research stations in Chamau (400 m) and Früebüel (1,000 m) in canton Zug, Switzerland. At both sites a fenced area of about $65 \mathrm{~m}^{2}$ was ploughed and divided into six plots $(3.5 \times 1.5 \mathrm{~m})$, which were weeded regularly and treated with molluscicide pellets to protect against slugs. E. апnиus seedlings were transplanted into two litre plastic pots filled with standard potting soil mixed with perlite (4:1) and slow release NPK fertilizer (Osmocote Exact Standard 8-9 months, Scotts; $0.5 \mathrm{~kg}$ per 1001 of soil and perlite mixture). The plants were watered regularly with tap water taken from the same source to ensure identical chemical composition. To reduce the risk of them drying out, the pots were set into the soil to $3 / 4$ of their height. In each plot 35 pots (one per clone) were arranged randomly in four rows.

Three treatments (control, competition and mowing) were applied to two plots per garden. In the plots with the competition treatment, about $0.4 \mathrm{~g}$ of grass seeds (Schweizer Uni-Lawn, Eric Schweizer Samen) were sown into the pots at the time of seedling transplant (May 2006). The grass mixture contained $28 \%$ of Lolium perenne, $45 \%$ of Festuca rubra, and $27 \%$ of Poa pratensis. The density and species composition were typical for an ordinary garden lawn. The short stature of the grasses implies that their competitive effect on E. annuиs was largely limited to below-ground resources. In the plots with mowing treatment, plants were clipped $5 \mathrm{~cm}$ above ground (about $90 \%$ of shoot mass was removed), when most of them started to flower, i.e. on 22-26 June at $400 \mathrm{~m}$ and on 6-12 July at $1,000 \mathrm{~m}$. This timing coincides with the main mowing season for extensively managed grasslands and roadsides in Switzerland.

\section{Plant measurements}

Plants were observed weekly to record the dates of important phenological changes-bolting (stem height $\geq 3 \mathrm{~cm}$ ), formation of flower buds, flowering, and seed set. Vegetative growth was assessed by measuring the number of stems and the number of leaves per stem after most of the plants started to flower. Additionally, the final height of all plants was measured after seed set. Reproductive output was assessed by collecting all inflorescences (stems with capitula without leaves) of control plants and plants grown with competitors on 15-19 August at $400 \mathrm{~m}$ and on 4-10 September at $1,000 \mathrm{~m}$. Inflorescences of mown plants were harvested on 6-8 October at $400 \mathrm{~m}$ and on 13-17 October at $1,000 \mathrm{~m}$. At each site the number of capitula was counted on 20 inflorescences in the control and mowing treatments. These were then dried at $70^{\circ} \mathrm{C}$ and weighed. Based on the linear relationships between inflorescence dry mass and number of capitula, the total number of capitula was estimated for the remaining plants. To assess plasticity in leaf shape, two leaves per clone were sampled from the upper part of the stems of mown plants in one plot per site, both before mowing and after plants had regrown. Photographs of the leaves were used to measure length $(L)$ and width $(W)$, and the ratio $L / W$ was obtained as shape parameter.

\section{Data analyses}

To analyse for treatment effects on vegetative growth and reproductive output, analysis of variance was used, where treatment and growth site (i.e. common garden) were treated as fixed factors, and plot (nested within treatment and site) and clone were treated as random factors. Due to non-normal distribution, data for the number of stems, the number of capitula per stem and the total number of capitula were square root transformed. The means of the treatments were compared to that of the control using Dunnett's method. Two-way analysis of variance was used to test for the effects of mowing, growth site and their interaction on leaf morphology.

For the plant phenology data, I performed survival analyses. The numbers of days to bolting, formation of flower buds, flowering and seed set were analysed by fitting survival curves with a Weibull distribution separately for each phenological transition. If a phenological transition was not reached, the observation was censored. The expected number of days needed for $50 \%$ of the plants to reach each phenological transition at either growth site was estimated separately for each treatment using survival models. All statistical analyses were performed in JMP 7.0.1 (SAS Institute Inc. 2007).

\section{Results}

All plants survived and grew well, but their performance was strongly affected by both the experimental treatments and the growth sites (Table 2). In all treatments, the number of stems, the total number of leaves and the total 
Table 2 ANOVA results $(F, P)$ for the fixed effects of treatment (Control, Competition, Mowing), growth site (400 m, 1,000 m asl) and their interaction on vegetative growth and reproductive output of E. annuus

\begin{tabular}{lccc}
\hline & Treatment $(T)$ & Site $(S)$ & $T \times S$ \\
\hline Number of stems & $132.37 * * *$ & $51.46 * * *$ & 3.56 \\
Leaves per stem & $586.82^{* * *}$ & $67.21 * * *$ & $31.50^{* *}$ \\
Total number of leaves & $17.72 * *$ & $24.38^{* *}$ & $4.91^{0.051}$ \\
Final height & $27.79 * * *$ & 10.42 & $5.94 *$ \\
Capitula per stem & $16.79 * *$ & $2.99 *$ & 0.52 \\
Total number of capitula & 0.13 & $50.93 * * *$ & 3.17 \\
\hline
\end{tabular}

$* P<0.05 ; * * P<0.01 ; * * * P<0.001$

number of capitula were lower at $1,000 \mathrm{~m}$ than at $400 \mathrm{~m}$ (Table 3). Control plants and plants grown with competitors tended to grow taller and have more leaves per stem at $1,000 \mathrm{~m}$ than at $400 \mathrm{~m}$ (i.e. significant treatment by site interactions in Table 2), but this was not the case for the mown plants.

The effect of competition on vegetative growth and reproduction was stronger at $1,000 \mathrm{~m}$ than at $400 \mathrm{~m}$ (Table 3). Compared to control plants, competition reduced the number of stems by $19 \%$ at $400 \mathrm{~m}$, but by $38 \%$ at $1,000 \mathrm{~m}$. The fewer stems did not lead to a lower reproductive output of plants with competitors at $400 \mathrm{~m}$, because more capitula were produced per stem. However, at $1,000 \mathrm{~m}$ competition reduced the reproductive output by $13 \%$ compared to control plants.

Mowing led to a vigorous regrowth in both common gardens (Table 3). Mown plants produced 127 and 86\% more stems than control plants at $400 \mathrm{~m}$ and at $1,000 \mathrm{~m}$, respectively. The effects of mowing on reproductive output were positive at $400 \mathrm{~m}$, but negative at $1,000 \mathrm{~m}$ due to a strong decrease in the number of capitula per stem. Mown plants produced $28 \%$ more capitula than control plants at $400 \mathrm{~m}$, but $28 \%$ fewer at $1,000 \mathrm{~m}$.

Leaf shape differed significantly between the two common gardens. Before mowing, leaves were narrower at $1,000 \mathrm{~m}$ than at $400 \mathrm{~m}($ length $(L) /$ width $(W)=3.57 \pm 0.08$
(SE) vs. $\left.3.09 \pm 0.08 ; F_{1,136}=4.1, P=0.044\right)$. Mowing had a significant effect on $E$. annuus leaf shape $\left(F_{1,136}=21.1\right.$, $P<0.0001)$, but this effect differed between altitudes $\left(F_{1,136}=11.9, P=0.0008\right)$. At $400 \mathrm{~m}$ the leaves produced after mowing $(\mathrm{L} / \mathrm{W}=3.79 \pm 0.10)$ were narrower than before (Fig. 1), but this was not the case at $1,000 \mathrm{~m}(L /$ $W=3.67 \pm 0.09)$.

All plants flowered and reproduced, except for two mown plants at $1,000 \mathrm{~m}$, which had flowered but not produced seeds by the end of the experiment (October 2006). Phenology was not influenced by competition, but seed set was postponed by mowing (Fig. 2). In all treatments, development was slower at $1,000 \mathrm{~m}$ than at $400 \mathrm{~m}$ (Fig. 2). Based on the estimated number of days for $50 \%$ of the plants to reach a phenological transition, the onset of seed production at $1,000 \mathrm{~m}$ was delayed by 19, 22 and 50 days in the control, competition and mowing treatment, respectively (Fig. 2).

\section{Discussion}

Effect of competition on growth and reproduction

Competition with grasses reduced the vegetative growth and reproductive output of $E$. annuus more at 1,000 $\mathrm{m}$ than at $400 \mathrm{~m}$. These results indicate that $E$. аnnuus can tolerate competition better at low altitudes than at higher altitudes, and therefore, its distribution at higher altitudes will probably be restricted to disturbed sites.

Other invasive plants have also been shown to be negatively affected by competition with native species and constrained to disturbed areas (Sala et al. 2007). However, some species may enhance their invasiveness by an adjustment of their phenology. For instance, the survival of two introduced plants, Senecio inaequidens and S. pterophorus that recently invaded protected areas in Catalonia (Spain), was dramatically reduced by resident vegetation when the establishment occurred in the spring, but not when the plants established in autumn, probably due to

Table 3 Means (SE) of vegetative growth and reproductive output of E. annuus in different treatments at either growth site

\begin{tabular}{|c|c|c|c|c|c|c|}
\hline & \multicolumn{3}{|l|}{$400 \mathrm{~m}$} & \multicolumn{3}{|l|}{$1,000 \mathrm{~m}$} \\
\hline & Control & Competition & Mowing & Control & Competition & Mowing \\
\hline Number of stems & $9.6 \pm 0.3$ & $7.8 \pm 0.3^{*}$ & $21.8 \pm 0.7^{*}$ & $7.7 \pm 0.3$ & $4.8 \pm 0.3^{*}$ & $14.3 \pm 0.5^{*}$ \\
\hline Leaves per stem & $25.2 \pm 0.3$ & $26.1 \pm 0.4$ & $15.2 \pm 0.2 *$ & $29.6 \pm 0.5$ & $29.3 \pm 0.5$ & $15.1 \pm 0.4^{*}$ \\
\hline Total number of leaves & $239.9 \pm 8.0$ & $202.2 \pm 8.3^{*}$ & $327.9 \pm 9.8^{*}$ & $226.3 \pm 8.1$ & $137.0 \pm 6.8^{*}$ & $210.7 \pm 7.9$ \\
\hline Final height $(\mathrm{cm})$ & $107.9 \pm 1.4$ & $113.2 \pm 1.5^{*}$ & $104.5 \pm 1.5$ & $117.8 \pm 1.3$ & $118.5 \pm 1.6$ & $102.6 \pm 1.1^{*}$ \\
\hline Capitula per stem & $350.8 \pm 24.6$ & $464.5 \pm 34.1^{*}$ & $197.5 \pm 11.1^{*}$ & $266.8 \pm 13.8$ & $447.7 \pm 42.4^{*}$ & $106.0 \pm 4.2 *$ \\
\hline Total number of capitula & $3,189 \pm 167$ & $3,312 \pm 167$ & $4,088 \pm 196^{*}$ & $1,947 \pm 83$ & $1,700 \pm 78 *$ & $1,404 \pm 50^{*}$ \\
\hline
\end{tabular}

Asterisks indicate that the comparison with the respective control was significant at a level of $P<0.05$ 
Fig. 1 Leaves sampled from the mid stems of the same clones at $400 \mathrm{~m}$ (a) before and (b) after mowing, and at $1,000 \mathrm{~m}(\mathbf{c})$ before and (d) after mowing
Fig. 2 Time estimates for $50 \%$ of the plants to reach different phenological transitions at 400 and $1,000 \mathrm{~m}$, as derived from survival models. Seedlings were planted at $400 \mathrm{~m}$ on 3 May and at $1,000 \mathrm{~m}$ on 5 May. Plants were mown when most of them started to flower
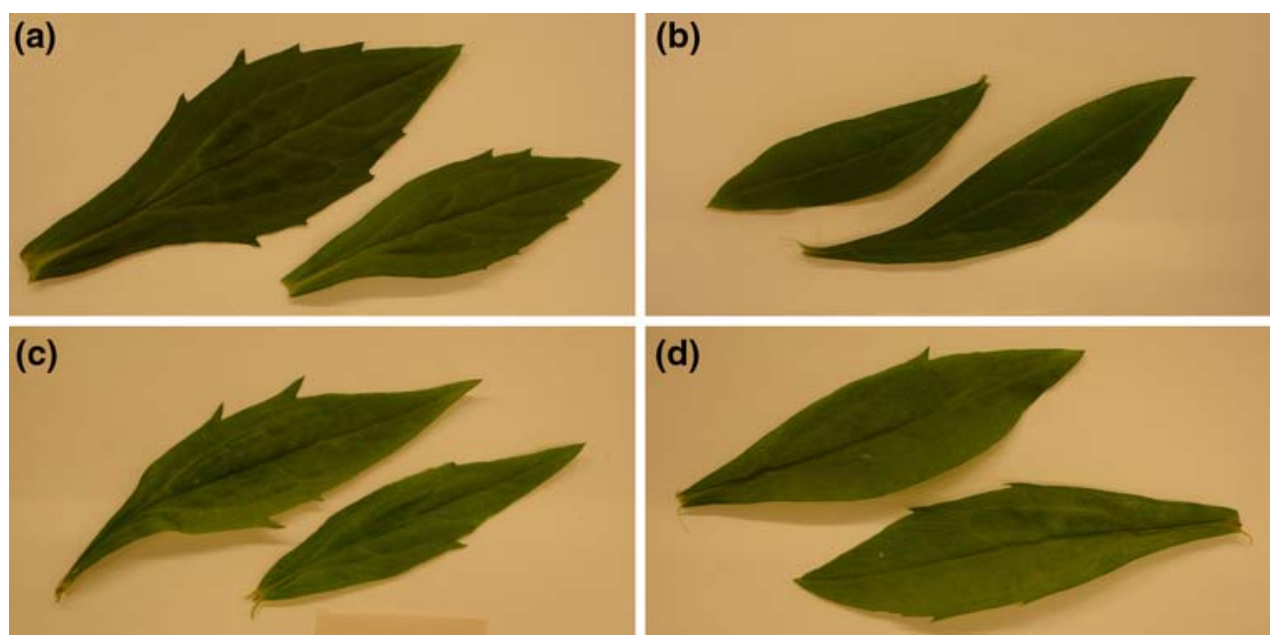

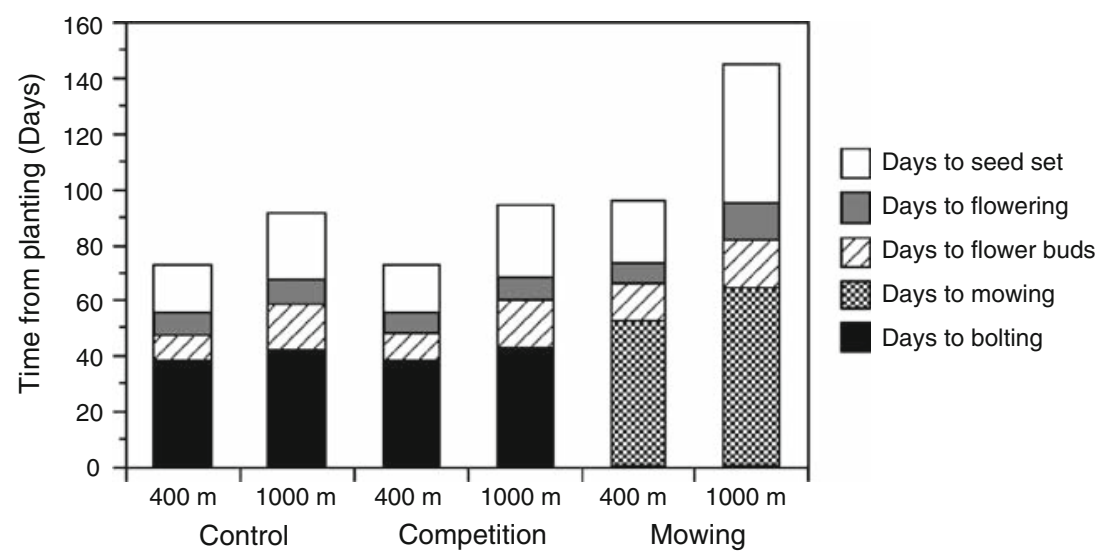

higher water availability (Cano et al. 2007). E. annuus usually produces seeds in autumn and overwinters as vegetative rosettes. Regehr and Bazzaz (1976) found that photosynthesis over winter enables $E$. annuus to accumulate energy reserves and gives the species competitive advantage over plants that germinate in spring. This ability might enhance the establishment of E. annuus even in more closed habitats.

A limitation of my study is that the competition treatment took place in nutrient-rich conditions and was only imposed after the seedlings had established. Competitive interactions between plants might be influenced by the initial size of competing individuals, and initially larger plants might be misjudged as competitively superior (Gibson et al. 1999; Connolly et al. 2001). The relative times at which plants establish may also play a role, as would be the case if the first plants to establish had a competitive advantage over those coming later (Ross and Harper 1972; White and Holt 2005). My results do therefore not imply that E. annuus would be able to establish and persist in dense vegetation, as it might be outcompeted in its early life stages. However, in habitats with gaps available for its initial establishment, it is able to reproduce and maintain a population, especially at low altitudes.

Effect of mowing on growth and reproduction

At 400 m mown E. annuus plants overcompensated both in terms of vegetative growth and reproductive output. Similar responses have been observed in other monocarpic plants grown without competition in high nutrient environments (Maschinski and Whitham 1989; Huhta et al. 2000), although such responses seem to be species specific (Moreno et al. 1999) and depend very much on plant architecture and position of meristems (Kimball and Schiffman 2003). Induction of overcompensation might also be restricted to a relatively short period of time, where the early limit is determined by the amount of resources available for regrowth, and the late limit depends on phenology and the amount of undifferentiated meristems (Lennartsson et al. 1998). However, in their old-field experiment, Joshi and Matthies (1996) did not observe any significant reduction in the cover of $E$. annuus even after 5 years of annual mowing. Therefore, the spread of 
E. annuus would probably not be prevented by mowing in the lowland regions.

In contrast, mowing might hinder E. annuus establishment at higher altitudes, as it strongly delayed plant phenology at $1,000 \mathrm{~m}$. Seed set in mown plants was postponed to the end of September, while control plants reproduced at the beginning of August. Therefore, there might not be enough time for seed germination and rosette formation before the onset of winter, which might strongly reduce the number of newly establishing plants. However, in another experiment I observed that the seed germination might be postponed to the following spring and that the annual life cycle changed to biennial (Trtikova et al. unpublished data). Thus, in disturbed sites at higher altitudes mowing might delay, but not prevent the spread of E. annuus.

\section{Effect of mowing on leaf shape}

I could confirm the observation of Frey et al. (2003) that in the lowlands mown E. annuus plants produced narrower leaves than unmown plants. Such a change in leaf morphology directly affects photosynthetic and respiratory capacities of the plants and might facilitate their regrowth (Fahnestock and Detling 2000). At 1,000 m however, the leaf shape of E. annuus was not affected by mowing, possibly because it was primarily determined by climatic conditions. In another experiment with E. annuus, I observed that rosette leaf traits, including specific leaf area, changed with altitude (Trtikova et al. unpublished data). I found no evidence that this was due to local adaptation, therefore, these responses are rather attributable to phenotypic plasticity that could enable $E$. annuus to better tolerate harsher climatic conditions at higher altitudes. Due to E. annuus' large plasticity in leaf shape, not only plants exposed to mowing, but also those originating from higher altitudes may have been mistakenly identified as a distinct taxon (i.e. E. annuus var. septentrionalis; Frey et al. 2003).

Acknowledgments Hans Leuenberger provided technical support at the ETH research stations in Chamau and Früebüel. Britta Jahn, Albert Kölbener, Miluse Kousalova, Daniel Schläpfer and Pavel Trtik kindly helped with fieldwork. I thank Sabine Güsewell, Peter Edwards, Matthias Baltisberger, Sonja Wipf and two anonymous reviewers for their helpful comments on the manuscript. This project was financed by a grant from the ETH Research Fund.

\section{References}

Becker T, Dietz H, Billeter R, Buschmann H, Edwards PJ (2005) Altitudinal distribution of alien plant species in the Swiss Alps. Perspect Plant Ecol Evol Syst 7:173-183
Brandon AL, Gibson DJ, Middleton BA (2004) Mechanisms for dominance in an early successional old field by the invasive nonnative Lespedeza cuneata (Dum. Cours.). G Don Biol Invasions 6:483-493

Cano L, Escarre J, Sans FX (2007) Factors affecting the invasion success of Senecio inaequidens and S. pterophorus in Mediterranean plant communities. J Veg Sci 18:281-288

Connolly J, Wayne P, Bazzaz FA (2001) Interspecific competition in plants: how well do current methods answer fundamental questions? Am Nat 157:107-125

Daehler CC (2003) Performance comparisons of co-occurring native and alien invasive plants: implications for conservation and restoration. Annu Rev Ecol Evol Syst 34:183-211

Edwards PJ, Frey D, Bailer H, Baltisberger M (2006) Genetic variation in native and invasive populations of Erigeron annuus as assessed by RAPD markers. Int J Plant Sci 167:93-101

Fahnestock JT, Detling JK (2000) Morphological and physiological responses of perennial grasses to long-term grazing in the Pryor Mountains, Montana. Am Midl Nat 143:312-320

Frey D, Baltisberger M, Edwards PJ (2003) Cytology of Erigeron annuus s.l. and its consequences in Europe. Bot Helv 113:1-14

Gibson DJ, Connolly J, Hartnett DC, Weidenhamer JD (1999) Designs for greenhouse studies of interactions between plants. J Ecol 87:1-16

Huhta AP, Hellstrom K, Rautio P, Tuomi J (2000) A test of the compensatory continuum: fertilization increases and belowground competition decreases the grazing tolerance of tall wormseed mustard (Erysimum strictum). Evol Ecol 14:353-372

Joshi J, Matthies D (1996) Effects of mowing and fertilization on succession in an old-field plant community. Bull Geobot Inst ETH 62:13-26

Kimball S, Schiffman PM (2003) Differing effects of cattle grazing on native and alien plants. Conserv Biol 17:1681-1693

Lennartsson T, Nilsson P, Tuomi J (1998) Induction of overcompensation in the field gentian, Gentianella campestris. Ecology 79:1061-1072

Maschinski J, Whitham TG (1989) The continuum of plant responses to herbivory: the influence of plant association, nutrient availability, and timing. Am Nat 134:1-19

Moreno DM, Nunez-Farfan J, Terrazas T, Muiz LD, Trinidad-Santos A, Trejo C, Larque-Saavedra A (1999) Plastic responses to clipping in two species of Amaranthus from the Sierra Norte de Puebla, Mexico. Genet Resour Crop Evol 46:225-234

Petryna L, Moora M, Nunes CO, Cantero JJ, Zobel M (2002) Are invaders disturbance-limited? Conservation of mountain grasslands in Central Argentina. Appl Veg Sci 5:195-202

Regehr DL, Bazzaz FA (1976) Low temperature photosynthesis in successional winter annuals. Ecology 57:1297-1303

Ross MA, Harper JL (1972) Occupation of biological space during seedling establishment. J Ecol 60:77-88

Sala A, Verdaguer D, Vila M (2007) Sensitivity of the invasive geophyte Oxalis pes-caprae to nutrient availability and competition. Ann Bot 99:637-645

Seastedt TR, Suding KN (2007) Biotic constraints on the invasion of diffuse knapweed (Centaurea diffusa) in North American grasslands. Oecologia 151:626-636

Stratton DA (1989) Competition prolongs expression of maternal effects in seedlings of Erigeron annuus (Asteraceae). Am J Bot 76:1646-1653

White VA, Holt JS (2005) Competition of artichoke thistle (Cynara cardunculus) with native and exotic grassland species. Weed Sci 53:826-833 